\title{
The Gender Wage Gap in Research Libraries
}

\section{Heather A. Howard, Meara M. Habashi, and Jason B. Reed}

\begin{abstract}
The gender wage gap impacts millions of women throughout the US and world, with women in the US making on average 82 percent of men's salaries (US Census Bureau, 2018). In research libraries, a field dominated by women, this has historically been true as well, with men rising to top positions at a higher rate and making more money than women in the same positions. Over the decades following the implementation of Affirmative Action, the number of women in administrative positions in research libraries has increased dramatically. This article explores the issue of women's salaries in research libraries in five job tiers. The five job tiers group library positions based on power dynamic, with the first tier including positions that run academic libraries, through the fifth tier, which includes front-line positions. An analysis of data from the Association of Research Libraries from 1976 through 2016 demonstrates that, though women have made progress in obtaining higher-level positions, salary disparities continue to exist between men and women at all levels.
\end{abstract}

\section{Introduction}

In the US, the gender wage gap has shrunk in the past decades but still has not disappeared, even though women have increasingly entered traditionally male occupations and women's educational attainment has surpassed men's. ${ }^{1}$ In 2016 and 2017, the Census Bureau reported that women made 80 percent of what men earned, and in 2018 the Pew Research Center put the number at 82 percent. ${ }^{2}$ Each year the National Committee on Pay Equity designates Equal Pay Day, an event that symbolizes how much further into the year women must work to earn what men earned the previous year. ${ }^{3}$ For 2019, the equal pay is April 2. While these numbers reflect the US as a whole, this is a problem even in female-dominated professions. This paper seeks to investigate the current status of the gender pay gap in research libraries, which are predominantly female, in the US and Canada and determine if improvements have occurred over time.

\section{Literature Review}

\section{Reasons for the Pay Gap}

The gender pay gap has long been linked to differences in experiences and work force interruptions, going back to Mincer and Polachek's seminal 1974 paper. ${ }^{4}$ They suggest that, under a

\footnotetext{
${ }^{*}$ Heather A. Howard is Assistant Professor, Libraries and School of Information Studies, at Purdue University; email: howar198@purdue.edu. Meara M. Habashi is Clinical Assistant Professor, Krannert School of Management, Jane Brock-Wilson Women in Management Center, at Purdue University; email: mhabashi@purdue.edu. Jason B. Reed is Assistant Professor, Libraries and School of Information Studies, at Purdue University; email: reed252@purdue. edu. (C2020 Heather A. Howard, Meara M. Habashi, and Jason B. Reed, Attribution-NonCommercial (https:// creativecommons.org/licenses/by-nc/4.0/) CC BY-NC.
} 
traditional division of family labor, with the woman as primary caregiver, women will anticipate leaving the workforce for prolonged periods during childbearing years. Due to this, they are less likely to seek on-the-job training than men. The reduced human capital investment and workforce experience lead to lower wages throughout a woman's career. Francine Blau found that women will avoid positions that require firm-specific training, which imparts skills only useful in a specific workplace, because the returns on these time investments can only be had by staying with a specific employer. ${ }^{5}$ Additionally, employers may show reluctance to hire women for these positions due to the costs associated with firm-specific training. This explainable difference has decreased over time as human capital investment of women has increased to match men. Francine Blau and Lawrence Kahn found that human capital factors accounted for 25.6 percent of the gender pay gap in 1979, but only 7.93 percent in 1998 as women improved their qualifications relative to men. ${ }^{6}$

The gender pay gap narrowed substantially throughout the 1980s; however, it has slowed since the 1990s, and an unexplained gap still remains. ${ }^{7}$ The reasons given for this gap vary, with some claiming it is due to women's lower ability to negotiate. ${ }^{8}$ Others say women do not perform as well in competitive environments, though this has been disputed. ${ }^{9}$ Another reason may be career-family tradeoffs, as women tend to place a higher priority on their families. Claudia Goldin suggests that workers who labor long hours and work specific hours are disproportionally rewarded and that women would benefit from changes in job structure to allow for more flexible work hours. ${ }^{10}$ A study of MBA graduates from the Booth School of Business at the University of Chicago found that, though there is a small gender differential at the outset of a career, by 10 to16 years postdegree, men are earning significantly more than women. ${ }^{11}$ This was found to be caused primarily by career interruptions and weekly hours worked. The gender pay gap may also be the result of implicit or explicit gender discrimination. ${ }^{12}$

Belinda Probert set out to examine gender inequity in higher education institutes in Australia, where men are far more likely than women to rise into high-level positions, which is also the case at universities in the US and UK. ${ }^{13}$ She found that, while women were more successful than men when they applied for a promotion, they were much less likely to actually apply. Her results showed that the absence of women in higher positions "would appear to be linked to the way households organize the division between paid and unpaid work rather than to discrimination against women in the workplace." ${ }^{14}$ As in other professions, women in academia are more often the primary caregivers in the home.

Though academic librarians are certainly a part of the larger academic community, this profession differs from many other disciplinary areas in that it is female-dominated. As Blau and Kahn note, "within female-dominated occupations, women tend to earn less than their male counterparts, and they tend to move up the career ranks more slowly. This phenomenon has been termed a glass escalator for men." ${ }^{15}$ Michelle Budig investigated the male advantage in male-dominated, female-dominated, and balanced jobs and found that men have an advantage of the same magnitude in all job types, both in pay levels and wage growth. ${ }^{16}$ Ruth Simpson interviewed male workers in the female-dominated professions of academic librarianship, cabin crew, nurses, and primary school teachers. ${ }^{17}$ Their experiences point to advantages in assumptions of enhanced leadership, differential treatment, and an association with a more careerist attitude.

\section{Gender Pay Gap in Academic Libraries}

When librarianship began to organize in the 1870s, it became an alternative for teaching as 
a career suitable for women. ${ }^{18}$ Librarianship fit within the acceptable bounds of "women's work," and male library leaders welcomed female library assistants due to their low wages. ${ }^{19}$ The American Library Association (ALA) was formed in 1876, with the first meeting including 90 men and 13 women. By 1910, librarianship was 78.5 percent female, and by 1920 it had reached nearly 90 percent. ${ }^{20}$ Throughout these early days of librarianship, women's wages were just a fraction of men's, and this unequal treatment was blamed on the weakness of women as a gender. ${ }^{21}$

In recent history, librarianship has been a female-dominated profession, with about one man for every five women. ${ }^{22}$ In 1991, 80 percent of the library workforce were women, whereas 80 percent of library management positions were held by men. By 1999, women had overtaken men and held a majority of top academic library leadership positions in Association of Research Libraries (ARL) institutions, the ARL board of directors, and the ALA's executive board and officer positions. ${ }^{23}$ This may be due, in part, to the impact in the subsequent decades of the Civil Rights Act of 1964, which prohibited discrimination based on race, color, religion, sex, or national origin in all employment practices. To help correct past discriminations, Executive Order 11246 created Affirmative Action in 1965, which aims to reduce discrimination toward targeted groups and increase their numbers in certain occupations and, starting in 1972, institutions of higher education. Three studies have examined the impact of Affirmation Action on administrators in academic libraries. Barbara Moran compared the status of women in academic libraries in 1972 and 1985 and found that women made advances in being appointed to mid-level administrative positions, especially assistant/associate director and department head level. ${ }^{24}$ This study was replicated by Coleen Sullivan in 1996 to determine if additional advances at the director level had been made since there were more women "in the pipeline" for top-level positions; she found the answer to be overwhelming affirmative, with women making significant gains in director, associate/assistant director, and department head positions. ${ }^{25}$ Barbara Moran, Elisabeth Leonard, and Jessica Zellers replicated the study once again in 2009 and found that women had made even more gains, now holding more administrative positions than men across the board in academic libraries. ${ }^{26}$ Most strikingly, the percentage of female ARL directors went from 2 percent in 1972 to 60 percent in 2004. Though women were close to parity in holding these administrative positions, those studies did not take salary into account. Darren Sweeper and Steven Smith looked at information on 357 college graduates working in libraries and found no significant differences in the earnings between women and men; however, the study does not distinguish between different types of libraries or librarianship. ${ }^{27}$ Recently, Quinn Galbraith, Adam Henry Callister, and Heather Kelley looked at 35 years of ARL salary data, as well as the 2014 ARL Salary Survey data, and found that the gender wage gap is substantially smaller in ARL libraries than in the workforce as a whole..$^{28}$

Starting salary can have a giant impact on the pay gap for librarians, given the nature of wages over time. As the vast majority of professional academic library positions are salaried, negotiating starting salary not only has an impact on the initial pay gap, but, given that raises are often percentage based, a pay gap would increase over time. Elise Silva and Quinn Galbraith found that male librarians were 38 percent more likely to negotiate their salary than female librarians. Even when women did negotiate, they were less successful than their male colleagues, who received on average an additional $\$ 825.35 .{ }^{29}$ However, there is evidence that negotiation rates, regardless of gender, increase with experience. ${ }^{30}$ Further, female librarians 
in administrative roles negotiate more than women in front-line positions and there is no statistical difference in negotiation rates between females and males in administrative positions, leaving the salary gap at this high level unexplained by negotiation. ${ }^{31}$

\section{Method}

\section{Data and Procedures}

To examine the effects of gender on research librarian salaries, data was compiled from the ARL Annual Salary Survey. ${ }^{32}$ The ARL "is a membership organization of libraries and archives in major public and private universities, federal government agencies, and large public institutions in Canada and the US." ${ }^{33}$ At the time of writing, there were 124 ARL institutions. ${ }^{34}$ This data set was selected because it was an existing, comprehensive data set that allowed for a retrospective analysis of salary across positions, sorted by sex and position type. Each year, ARL publishes an annual report summarizing the salary of professional staff across ARL member libraries. The report includes salary analyzed by a variety of demographic variables including sex, race, years of experience, and position. The current study includes data across 41 years, from academic year 1976-1977 to 2016-2017, and focuses on gender as the variable of interest, which was derived from the sex survey field. The specific data set used for this study includes only ARL University Libraries, excluding medical and law libraries, which ARL reports differently. For the purposes of this study, "research librarian" is defined as professional staff/ librarians employed at an ARL Library.

\section{Results}

\section{Proportion of Men as Librarians}

To examine the distribution of males and females in the field of research librarians, a variable representing the proportion of men in these positions was created. This variable divided the

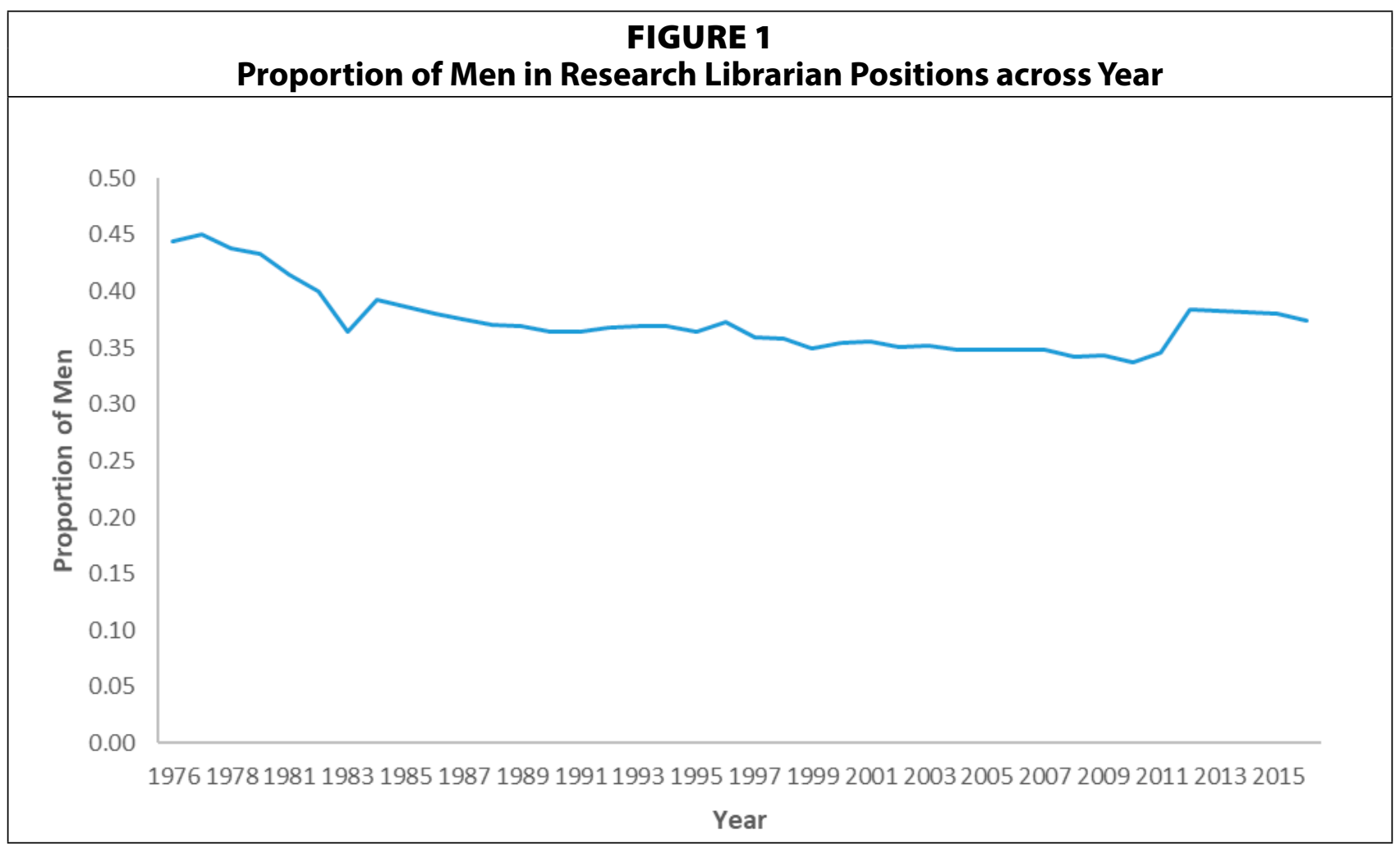


number of men in all research librarian positions by the total number of research librarians. Therefore, values closer to 1.0 represent a larger number of men.

We submitted this dependent variable to a one-way ANOVA with year as the predictor variable. As seen in figure 1, the proportion of men seems to steadily decrease over the 41-year period (with the exception of 2010-2012), but there was no

\begin{tabular}{|l|l|}
\hline \multicolumn{2}{|c|}{ TABLE 1} \\
Positions within Each Tier or Level of Power \\
\hline Tier & Positions \\
\hline 1 & Directors, Deans \\
\hline 2 & Associate Directors, Assistant Directors \\
\hline 3 & Branch Heads \\
\hline 4 & Department Heads \\
\hline 5 & $\begin{array}{l}\text { Specialists, Public Services, Technical Services, } \\
\text { Research, Catalogers }\end{array}$ \\
\hline
\end{tabular}
significant change in the proportion of men across that period, $F(1,939)=1.134, p=0.266$.

To examine the gender makeup of research librarians across different types of position and levels of power, a variable was created indicating the level of organizational power held by the individual within the position. The ARL data includes salary broken down by sex and position (such as director, assistant director, branch head). Each of the positions was assigned to one of five tiers based on the level of decision-making power assigned to the individual within the position. (For a summary list of all positions by tier, see table 1.) Two coders, trained research librarians, categorized each of the positions and had 100 percent agreement.

First, the proportion of men in each tier across all years was submitted to a one-way ANOVA with tier as the predictor variable and proportion of men as the dependent variable. As seen in figure 2, the proportion of men is much greater in the higher-tiered positions (such as director) than lower-tiered positions, $F(1,974)=99.368, p<0.001$. More specifically, the proportion of men consistently decreases as the level of organizational power decreases. In fact, in Tier 1 positions across all years, the proportion of men $(M=0.60)$ is almost double the proportion of men in the lowest-tier (Tier 5) positions $(M=0.32)$.

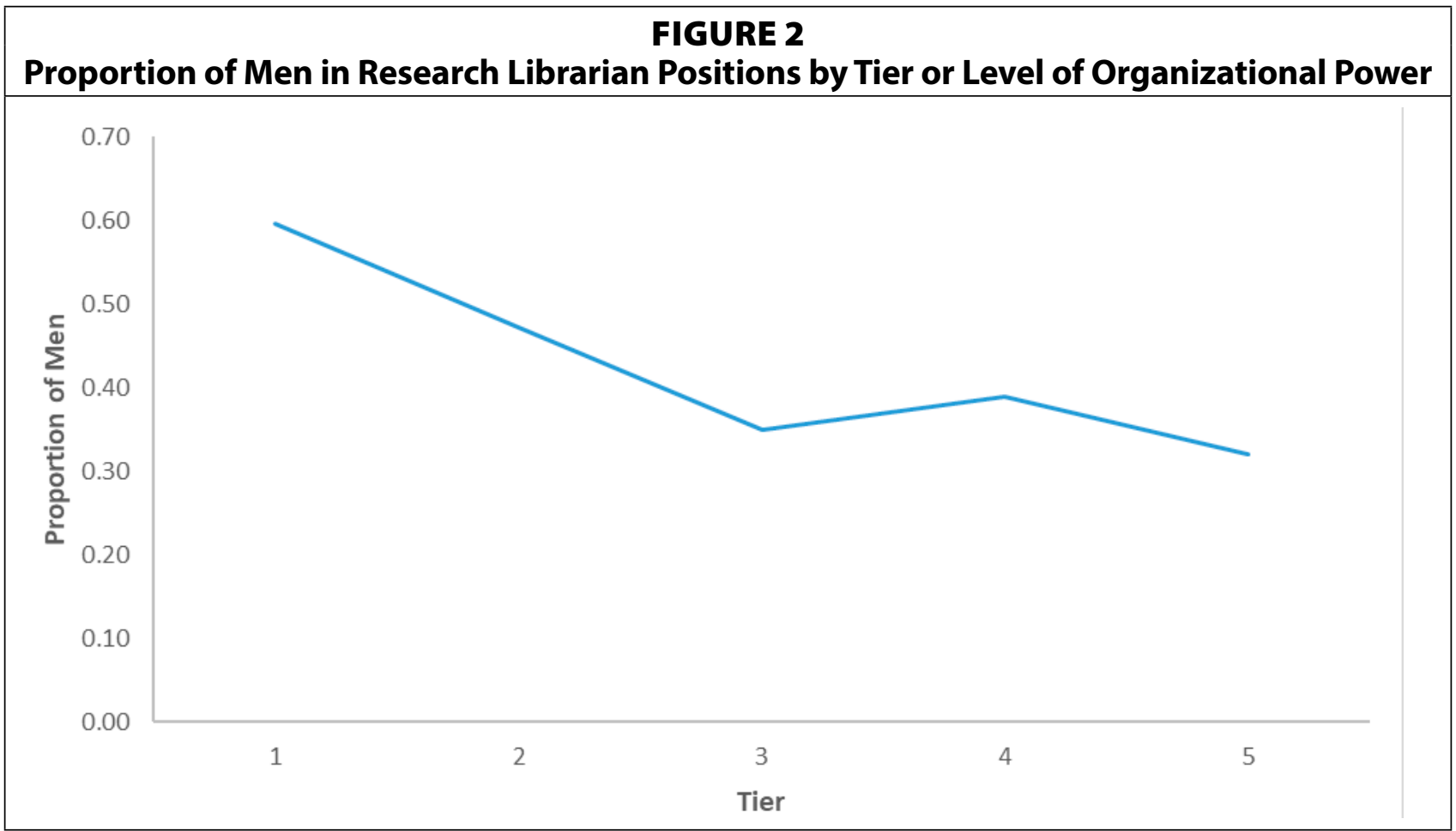




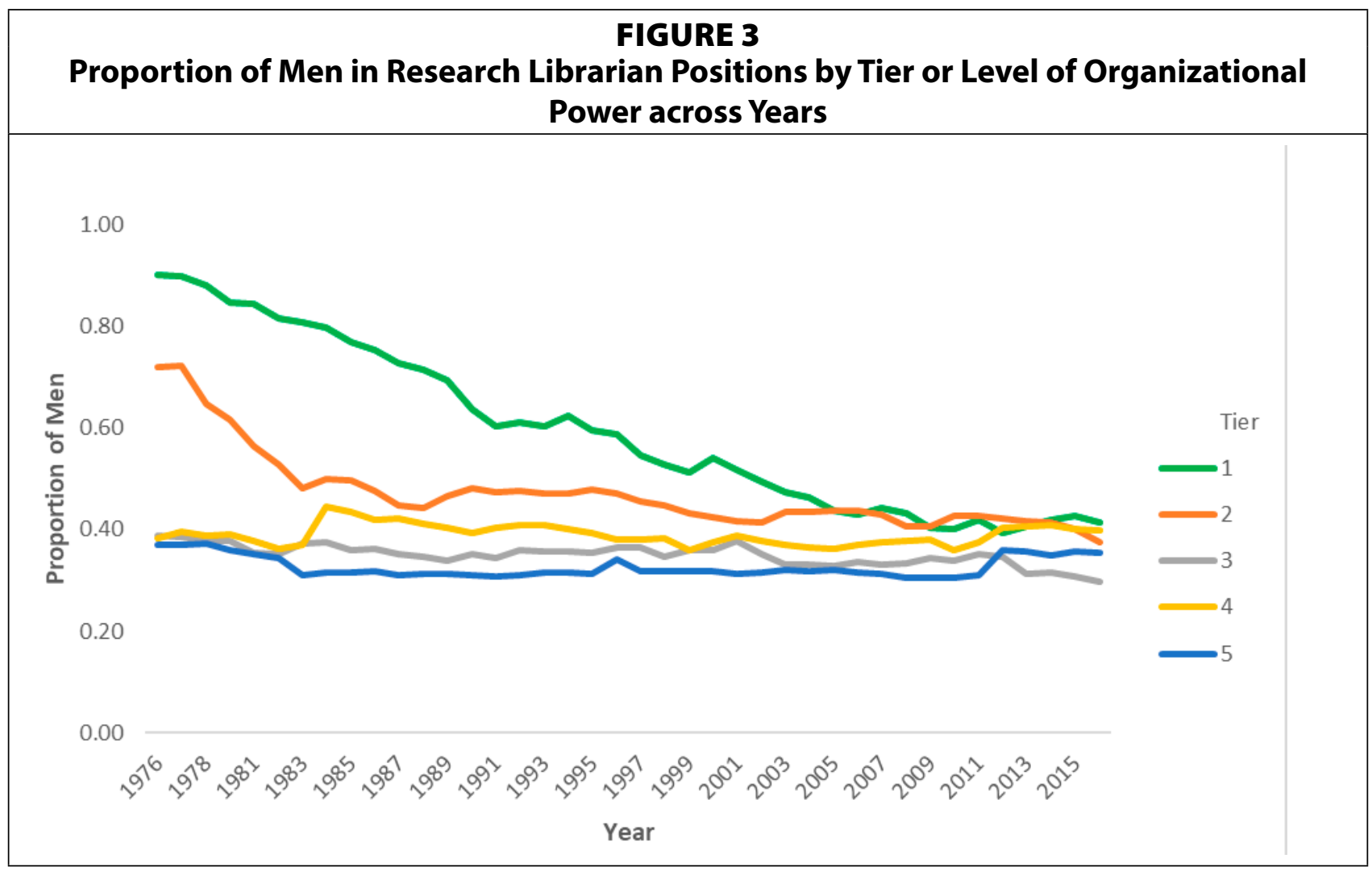

Next, this difference in gender makeup across positions by year was examined. As seen in figure 3, the proportion of men in higher-power positions (Tiers 1 and 2) has steadily decreased across the years, $F(39,80)=3.264, p<0.001$, but has remained the same in lower-level positions (Tiers 3,4 , and 5$), F(39,819)=0.423, p=0.999$.

\section{Wage Gap for Research Librarians}

To examine the gender wage gap among research librarians, a variable representing the wage ratio was created. This variable was created by dividing the average salary for women by the corresponding average salary for men in the same position that year. Therefore, values less than 1.0 indicate women earned less than men in that position, while values greater than 1.0 indicate women earned more than men in that position. It is important to note that the overall average salary ratio across position and year was 0.975 ; therefore, the wage gap in research librarians is significantly smaller than the national wage gap for 2016 of $0.82 .{ }^{35}$

This dependent variable was submitted to a one-way ANOVA with year as the predictor variable. (All salary analyses control for yearly inflation rate.) As seen in figure 4, the salary ratio has always been lower than 1.0, indicating that men have always made slightly more than women. Results reveal there was a significant change in salary ratio across the 40-year period, $F(1,939)=1.458, p=0.038$. Women earned significantly less than men in the 1980s, their salaries increased throughout the ' 80 s and '90s, then slowly decreased or remained the same in the 21st century (2000-2016). However, it is important to note that the salary ratio $(M=0.974)$ in the last year of data $(2016)$ is higher than the salary ratio $(M=0.953)$ in the first year of data $(1976)$, indicating women have made 


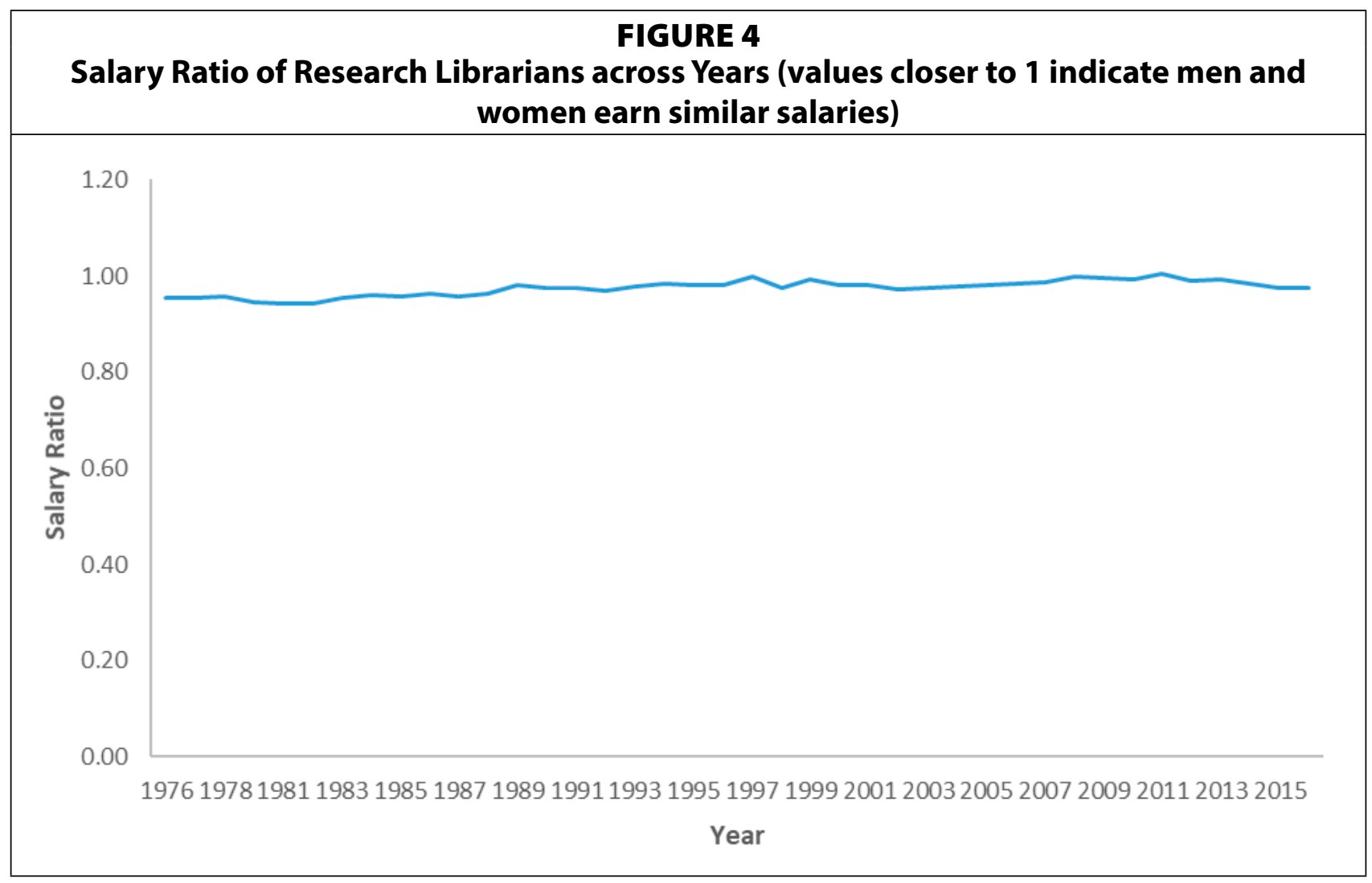

strides in their earning potential, although these gains are not significantly higher, $F(1,34)=1.48, p=0.232$.

To determine the effect of organizational power on salary ratio, the salary ratio in each tier was examined separately (see table 1 for tier definitions). One sample ttests were conducted for each tier with 1.0 (the value of the ratio representing equal pay

TABLE 2

\begin{tabular}{|l|l|l|}
\multicolumn{3}{|c|}{ Comparison of Salary Ratios to Equity Index } \\
\hline Tier & Ratio & Test for Difference from 1 \\
\hline 1 & .9881 & $\mathrm{t}(39)=-2.497, \mathrm{p}=0.017$ \\
\hline 2 & .969 & $\mathrm{t}(79)=-8.839, \mathrm{p}<0.001$ \\
\hline 3 & .9157 & $\mathrm{t}(39)=-26.461, \mathrm{p}<0.001$ \\
\hline 4 & .983 & $\mathrm{t}(341)=-4.721, \mathrm{p}<0.001$ \\
\hline 5 & .9754 & $\mathrm{t}(477)=-13.201, \mathrm{p}<0.001$ \\
\hline
\end{tabular}
for women and men) set as the test value. As illustrated in table 2, women are consistently earning less than men in all positions and at all levels of organizational power.

Next, salary ratio across positions by year was examined. As seen in figure 4 and stated previously, salary ratio for research librarians has changed slightly across the 41-year period; however, the difference in the salary ratio from 1976 to 2016 is not significantly different.

This is surprising, since the number of men in high level positions has significantly decreased. To more closely examine this effect, we conducted a correlational analysis examining how salaries for men and women change as the salary ratio changes. Results indicate that there is no relationship between men's salaries and the salary ratio (in other words, the gender gap), $r=0.015, p=0.634$. However, there is a significant relationship between the salary ratio and women's salary, $r=0.111, p<0.001$. As shown in figure 6 , as the wage gap increases and the salary ratio gets smaller, indicating that women are earning less compared to men, women are earning less in salary but men's salary is unchanging. More specifically, 
FIGURE 5

Salary Ratio for Research Librarian Positions by Tier or Level of Organizational Power across Years (values closer to 1 indicate men and women earn similar salaries)

1.20

1.00

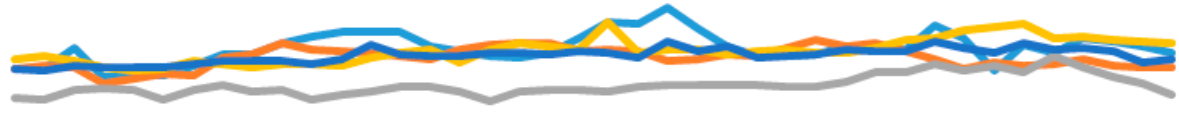

0.80

을

焉

0.40

0.20

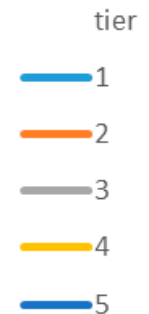

0.00

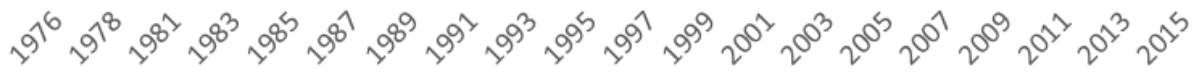

Year

FIGURE 6

Average Salary for Men and Women at Different Levels of the Wage Gap across Years and Tiers

\section{0}

55000

54000

53000

52000

$\geq 51000$

贾

50000

49000

48000

47000

46000

45000

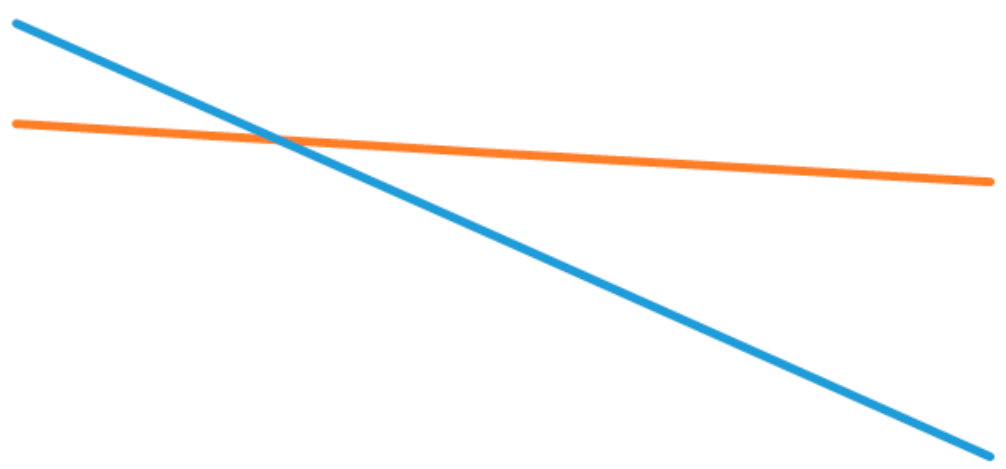


the wage gap in research librarians seems to be because women are earning less compared to their male counterparts, not because of changes in men's salaries. This may be an initial indication that, when the wage gap exists, it is because women are undervalued, while the value of men seems to be unchanging.

\section{Years of Experience for Research Librarians}

One possible explanation for the gender wage gap in research librarians is that men have spent more time in these positions than women and therefore received more raises and salary adjustments. To rule out this possibility, we examined gender differences in years of experience at each tier. Years of experience was collected as part of the larger survey starting in 1983; therefore, the current analysis includes data from 1983 on. We created a "years of experience" difference variable by subtracting the average years of experience of women from the average years of experience of men. Positive values indicate men had more experience, while negative values indicate women had more experience. Results revealed that experience differences existed at each tier, but this pattern was inconsistent, $F(1,787)=12.333, p<0.001$. As illustrated in table 3 , the pattern of which group has more experience is inconsistent across tiers; therefore, experience cannot be a plausible explanation for the gender wage gap.

\begin{tabular}{|l|c|c|}
\hline \multicolumn{4}{c|}{ TABLE 3 } \\
\hline Tier & Difference in Years of Experience for Men and Women across Tiers \\
\hline 1 & 1.132 & Group with More Experience \\
\hline 2 & -.545 & Men \\
\hline 3 & .761 & Women \\
\hline 4 & -.302 & Men \\
\hline 5 & .127 & Women \\
\hline *Note: Positive values indicate men had more years of experience. \\
\hline
\end{tabular}

\section{Discussion}

At first glance, the overall results indicate an increase in representation for women at all levels of authority, including leadership positions, and a very small wage gap, with women making 97 percent of what men are paid. However, when investigating the salary information based on tiered positions, this study shows that, while women are becoming more represented in administrative positions (tiers 1 and 2), they are still experiencing a significant wage gap in those positions. Efforts by ARL libraries to increase female representation in leadership positions was and continues to be effective. This claim can be seen in the large increase in women in tiers 1 and 2 since the implementation of Affirmative Action in higher education in 1972. Now the same effort and attention needs to be spent on eliminating the wage gap. This is especially important considering that the wage gap is present even in entry-level positions, where women far outnumber men.

Although the gap in wages seems to be small, with ratios above .90 in all tiers, beginning with any gap in wages can compound over time. Looking at tier 1, where the salary ratio is closest to 1 (see table 2 for ratios by tier), indicating the smallest wage gap, differences in salary compound over time. Taking the average salary for men $(\$ 127,207.42)$ and women 
$(\$ 126,166.67)$ in tier 1 across all years and submitting it to an annual increase of 3.69 percent (the average Cost of Living Adjustment reported by the Social Security Administration across 1976-2016) indicates that women will make $\$ 55,460.36$ less than men across 29 years of work (the average years of experience for men and women at tier 1$).{ }^{36}$ Turning to tier 3 , which has the salary ratio furthest from 1 , indicating the largest wage gap, this salary difference increases to $\$ 139,161.54$ across 20 years (the average years of experience for men and women at tier 3 ). And this difference in salary gets larger for each additional year in work. Starting at a lower salary leads to an inability to catch up later. More research needs to be conducted to discover what is causing the wage gap to appear and increase as women move up the hierarchical ladder. Identifying the cause/s, whether it be a lack of negotiation, systemic discrimination in the level of wages offered to successful candidates, or other reasons, will allow ARL member libraries to develop an effective strategy for correcting this imbalance. One possible explanation for the improvement in representation, but not wage equality, is that representation is more visible than wages, which is often private information, and attention on the underrepresentation of women in leadership roles leads to active measures to improve the ratio.

Interestingly, the proportion of men in ARL institutions has been steadily decreasing, with the exception of two years. The most dramatic was in 2011, which showed a large positive increase in male employment. While the percentages return to a downward trend, the subsequent changes have been very small. The authors are unsure of what caused this huge jump, but suspect it could be related to economic recession that began in 2007, which would have impacted research librarians finishing college and entering the workforce in 2011. However, it should be noted that the percentage of males in ARL institutions (38\%) is higher than the ALA percentage (19\%), according to the most recent data from both organizations. ${ }^{37}$ ALA numbers would reflect not only academic librarians, but also public and school librarians, who tend to have lower wages. ${ }^{38}$

\section{Limitations}

While mostly a strong data set, there are some definite limitations to the ARL salary data. First, it only includes ARL institutions; as such, the trends in representation and wage gap may not be the same across all university, college, public, and special libraries. Second, ARL collects information on the number of hierarchical tiers at each institution, but this data is not connected to the salary information, which required the authors to assign job titles to a most likely tier. Finally, because the tiers had to be assigned, there could be an argument made for moving different job classifications to different tiers, particularly in regard to branch heads. Comparisons between organizations are further complicated by diversity in regard to staffing size between libraries and their respective organizational structures.

\section{Potential Bias}

There is always a possibility of error when dealing with large data sets; but, because the ARL salary information is collected by each institution's respective dean, or their proxy, for the purposes of creating the annual report, there is little reason to suspect systemic bias in the reporting.

\section{Recommendations}

The first recommendation is that ARL should change their guidelines for collecting data and 
move from collecting data based on "sex" to that of data based on gender information. Though the authors made the determination to use the sex variable collected by ARL to determine the gender wage gap, we recommend ARL update this field to collect gender information, which is self-identified, as opposed to sex, which is defined at birth. Additionally, the data collection should acknowledge that gender is nonbinary and allow for full representation of employees in ARL member libraries. In terms of accountability, ARL could make a public presentation on the current status of representation across all job tiers and the current wage gap. Discussion of salary can be a taboo topic, which can hamper efforts to eliminate the gap. Acknowledging the existence of the pay gap would bring the discussion into the open, where the additional public scrutiny could help address and correct the existing wage gap. This could encourage individual libraries to evaluate their pay structures to determine in what ways they are contributing to this problem. Publicly addressing this would reflect the librarian beliefs in open data, highlight the existing gap, and (we hope) one day allow for a celebration of the elimination of the wage gap across all tiers.

\section{Future Research}

Additional research in the form of surveys, interviews, and focus groups might help identify the cause/s of the continuing wage gap. A similar effort to collect salary data across all academic libraries could determine if the findings from this study are indeed prevalent across all academic libraries or an issue in just ARL libraries. Additionally, a natural follow-up to this study would be to investigate potential issues in representation and/or wage gap for underrepresented minorities in libraries.

\section{Conclusion}

This study shows that, while research libraries have always been a female-dominated profession, that dominance was not always present in the highest levels of authority. There have been successful efforts to work on the issue of representation, but the same cannot be said for equal pay between males and females. While better than the US overall pay gap, males at every level make significantly more, both statistically and in terms of lost wages during the course of a career, than their female colleagues. Further research should be conducted to discover the cause/s of the pay gap, and every effort should be made to correct the imbalance. These efforts should be inclusive of the entire workforce and could include implicit bias training, increased mentoring opportunities, and professional development opportunities available through conferences and webinars. A systemic issue requires acknowledgment and support throughout the profession for industrywide changes to be successful. It is also important to bring the discussion of the gender wage gap into the open. It is hoped that talking about the wage gap can reduce the taboo of discussing salary, both at an individual and public level, and lead to changes like those experienced in the more visible area of representation.

\section{Notes}

1. Francine D. Blau and Lawrence M. Kahn, "Gender Differences in Pay," Journal of Economic Perspectives 14, no. 4 (2000): 75-99; Claudia Goldin, "The Quiet Revolution That Transformed Women's Employment, Education, and Family," American Economic Review 96, no. 2 (2006): 1-21; Claudia Goldin, Lawrence F. Katz, and Ilyana Kuziemko, "The Homecoming of American College Women: The Reversal of the College Gender Gap," Journal of Economic Perspectives 20, no. 4 (December 2006): 133-56, https://doi.org/10.1257/jep.20.4.133.

2. Nikki Graf, Anna Brown, and Eileen Patten, "The Narrowing, but Persistent, Gender Gap in Pay," Pew 
Research Center (April 9, 2018), www.pewresearch.org/fact-tank/2018/04/09/gender-pay-gap-facts/; US Census Bureau, "Income and Poverty in the United States: 2016" (September 12, 2017), https://www.census.gov/library/ publications/2017/demo/p60-259.html; US Census Bureau, "Income and Poverty in the United States: 2017" (September 12, 2018), https://www.census.gov/library/publications/2018/demo/p60-263.html.

3. National Committee on Pay Equity, "Equal Pay Day," https://www.pay-equity.org/day.html [accessed January 7, 2019].

4. Jacob Mincer and Solomon Polachek, "Family Investments in Human Capital: Earnings of Women," Journal of Political Economy 82, no. 2 (1974): S76-108.

5. Francine D. Blau and Anne E. Winkler, The Economics of Women, Men, and Work, 8th ed. (New York, NY: Oxford University Press, 2018).

6. Francine D. Blau and Lawrence M. Kahn, The US Gender Pay Gap in the 1990s: Slowing Convergence (Princeton, NJ: Industrial Relations Section, Princeton University, 2006).

7. Francine D. Blau and Lawrence M. Kahn, “The Gender Wage Gap: Extent, Trends, and Explanations," NBER Working Paper Series (National Bureau of Economic Research, January 2016), https://www.nber.org/ papers/w21913.pdf.

8. Linda Babcock and Sara Laschever, Women Don't Ask: Negotiation and the Gender Divide (Princeton, NJ: Princeton University Press, 2003), http://ebookcentral.proquest.com/lib/purdue/detail.action?docID=445436.

9. Nabanita Datta Gupta, Anders Poulsen, and Marie Claire Villeval, "Male and Female Competitive Behavior: Experimental Evidence," GATE Working Paper No. W.P.05-12 (Rochester, NY: Social Science Research Network, November 1, 2005), https://papers.ssrn.com/abstract=906766; Alan Manning and Farzad Saidi, “Understanding the Gender Pay Gap: What's Competition Got to Do with It?" ILR Review 63, no. 4 (July 1, 2010): 681-98, https:// doi.org/10.1177/001979391006300407; Uri Gneezy, Muriel Niederle, and Aldo Rustichini, "Performance in Competitive Environments: Gender Differences," Quarterly Journal of Economics 118, no. 3 (2003): 1049-74; Uri Gneezy, Kenneth L. Leonard, and John A. List, "Gender Differences in Competition: Evidence from a Matrilineal and a Patriarchal Society," Econometrica 77, no. 5 (2009): 1637-64.

10. Claudia Goldin, "A Grand Gender Convergence: Its Last Chapter," American Economic Review 104, no. 4 (April 2014): 1091-119, https://doi.org/10.1257/aer.104.4.1091.

11. Marianne Bertrand, Claudia Goldin, and Lawrence F. Katz, "Dynamics of the Gender Gap for Young Professionals in the Financial and Corporate Sectors," American Economic Journal: Applied Economics 2, no. 3 (2010): 228-55.

12. Marianne Bertrand, Dolly Chugh, and Sendhil Mullainathan, "Implicit Discrimination," American Economic Review 95, no. 2 (2005): 94-98; John T. Jost et al., "The Existence of Implicit Bias Is beyond Reasonable Doubt: A Refutation of Ideological and Methodological Objections and Executive Summary of Ten Studies That No Manager Should Ignore," Research in Organizational Behavior 29 (January 1, 2009): 39-69, https://doi.org/10.1016/j. riob.2009.10.001; Ernesto Reuben, Paola Sapienza, and Luigi Zingales, “How Stereotypes Impair Women's Careers in Science," Proceedings of the National Academy of Sciences of the United States of America 111, no. 12 (2014): 4403-08; P.A. Riach and J. Rich, "Field Experiments of Discrimination in the Market Place," Economic Journal 112, no. 483 (2002): F480-518.

13. Belinda Probert, "'I Just Couldn't Fit It In': Gender and Unequal Outcomes in Academic Careers," Gender, Work E Organization 12, no. 1 (2005): 50-72, https://doi.org/10.1111/j.1468-0432.2005.00262.x; Kristen Monroe et al., "Gender Equality in Academia: Bad News from the Trenches, and Some Possible Solutions," Perspectives on Politics 6, no. 2 (June 2008): 215-33, https://doi.org/10.1017/S1537592708080572; Liza Howe-Walsh and Sarah Turnbull, "Barriers to Women Leaders in Academia: Tales from Science and Technology," Studies in Higher Education 41, no. 3 (March 3, 2016): 415-28, https://doi.org/10.1080/03075079.2014.929102.

14. Probert, "I Just Couldn't Fit It In," 65.

15. Francine D. Blau, Marianne A. Ferber and Anne E. Winkler, The Economics of Women, Men, and Work (New York, NY: Pearson, 2013), 286.

16. Michelle J. Budig, "Male Advantage and the Gender Composition of Jobs: Who Rides the Glass Escalator?" Social Problems 49, no. 2 (2002): 258-77, https://doi.org/10.1525/sp.2002.49.2.258.

17. Ruth Simpson, "Masculinity at Work: The Experiences of Men in Female Dominated Occupations," Work, Employment and Society 18, no. 2 (June 1, 2004): 349-68, https://doi.org/10.1177/09500172004042773.

18. Barbara E. Brand, "Librarianship and Other Female-Intensive Professions," Journal of Library History (1974-1987) 18, no. 4 (1983): 391-406.

19. Dee Garrison, "The Tender Technicians: The Feminization of Public Librarianship, 1876-1905," Journal of Social History 6, no. 2 (December 1, 1972): 131-59, https://doi.org/10.1353/jsh/6.2.131.

20. Dee Garrison, Apostles of Culture: The Public Librarian and American Society, 1876-1920 (New York, NY: Macmillan Information, 1979). 
21. Mary Biggs, "Librarians and the 'Woman Question': An Inquiry into Conservatism," Journal of Library History (1974-1987) 17, no. 4 (1982): 409-28.

22. American Library Association website, "Diversity Counts" (March 29, 2007), www.ala.org/aboutala/offices/diversity/diversitycounts/divcounts.

23. Sarla R. Murgai, "Attitudes toward Women as Managers in Library and Information Science," Sex Roles 24, no. 11 (June 1, 1991): 681-700, https://doi.org/10.1007/BF00288206; Marta Mestrovic Deyrup, "Is the Revolution Over? Gender, Economic, and Professional Parity in Academic Library Leadership Positions," College E Research Libraries 65, no. 3 (May 2004): 242-50.

24. Barbara B. Moran, "The Impact of Affirmative Action on Academic Libraries," Library Trends, Fall 1985 (1985): 20.

25. Coleen J. Sullivan, "Affirmative Action and Women in Academic Libraries: How Far Have We Come?" (Chapel Hill, NC: University of North Carolina at Chapel Hill, 1996).

26. Barbara B. Moran, Elisabeth Leonard, and Jessica Zellers, "Women Administrators in Academic Libraries: Three Decades of Change," Library Trends 58, no. 2 (2009): 215-28, https://doi.org/10.1353/lib.0.0088.

27. Darren Sweeper and Steven A. Smith, "Assessing the Impact of Gender and Race on Earnings in the Library Science Labor Market," College \& Research Libraries 71, no. 2 (2010): 171-83, https://doi.org/10.5860/0710171.

28. Quinn Galbraith, Adam Henry Callister, and Heather Kelley, "Have Academic Libraries Overcome the Gender Wage Gap? An Analysis of Gender Pay Inequality | Galbraith I College \& Research Libraries," https:// doi.org/10.5860/crl.80.4.470.

29. Elise Silva and Quinn Galbraith, "Salary Negotiation Patterns between Women and Men in Academic Libraries," College E Research Libraries 79, no. 3 (2018), https://doi.org/10.5860/crl.79.3.324.

30. Leo S. Lo and Jason B. Reed, "'You're Hired!': An Analysis of the Perceptions and Behaviors of Library Job Candidates on Job Offer Negotiations," Southeastern Librarian 64, no. 2 (2016).

31. Silva and Galbraith, "Salary Negotiation Patterns between Women and Men in Academic Libraries."

32. Suzanne Frankie, "ARL Annual Salary Survey 1976-1977" (Chicago, IL: Association of Research Libraries [ARL], 1977); Suzanne Frankie, "ARL Annual Salary Survey 1977-1978" (ARL, 1978); Gordon Fretwell, "ARL Annual Salary Survey 1978-1979" (ARL, 1980); Gordon Fretwell, "ARL Annual Salary Survey 1979-1980" (ARL, 1980); Gordon Fretwell, “ARL Annual Salary Survey 1981" (ARL, 1982); Gordon Fretwell, "ARL Annual Salary Survey 1982" (ARL, 1982); Gordon Fretwell, "ARL Annual Salary Survey 1983" (ARL, 1984); Gordon Fretwell, "ARL Annual Salary Survey 1984" (ARL, 1984); Gordon Fretwell, “ARL Annual Salary Survey 1985" (ARL, 1986); Gordon Fretwell, "ARL Annual Salary Survey 1986" (ARL, 1987); Gordon Fretwell, "ARL Annual Salary Survey 1987" (ARL, 1988); Gordon Fretwell, “ARL Annual Salary Survey 1988” (ARL, 1988); Gordon Fretwell, “ARL Annual Salary Survey 1989" (ARL, 1990); Gordon Fretwell and Nicola Daval, "ARL Annual Salary Survey 1992" (ARL, 1992); Gordon Fretwell, Nicola Daval, and Patricia Brennan, "ARL Annual Salary Survey 1993" (ARL, 1994); Gordon Fretwell and Martha Kyrillidou, "ARL Annual Salary Survey 1994" (ARL, 1995); Gordon Fretwell and Sarah Pritchard, "ARL Annual Salary Survey 1990" (ARL, 1991); Gordon Fretwell and Sarah Pritchard, "ARL Annual Salary Survey 1991" (ARL, 1992); Martha Kyrillidou and Les Bland, "ARL Annual Salary Survey 2009-2010" (December 17, 2010), https://publications.arl.org/ARL-Annual-Salary-Survey-2009-2010/; Martha Kyrillidou, Julia C. Blixrud, and Jonathan Green, "ARL Annual Salary Survey 1998-1999" (ARL, 1999); Martha Kyrillidou, Julia C. Blixrud, and Ken Rodriguez, "ARL Annual Salary Survey 1997-1998" (Association of Research Libraries, 1998); Martha Kyrillidou, Mark Young, and Jason Barber, “ARL Annual Salary Survey 2007-2008," October 21, 2008, https://publications.arl.org/ARL-Annual-Salary-Survey-2007-2008/; Martha Kyrillidou and Kimberly Maxwell, "ARL Annual Salary Survey 1995-1996" (ARL, 1995); Martha Kyrillidou and Kimberly Maxwell, "ARL Annual Salary Survey 1996-1997" (ARL, 1996); Martha Kyrillidou and Shaneka Morris, "ARL Annual Salary Survey 2010-2011" (October 31, 2011), https://publications.arl.org/ARL-Annual-Salary-Survey-2010-2011/; Martha Kyrillidou and Shaneka Morris, "ARL Annual Salary Survey 2011-2012" (August 2, 2012), https://publications.arl.org/ ARL-Annual-Salary-Survey-2011-2012/; Martha Kyrillidou and Shaneka Morris, "ARL Annual Salary Survey 2012-2013" (November 19, 2013), https://publications.arl.org/ARL-Annual-Salary-Survey-2012-2013/; Martha Kyrillidou and Shaneka Morris, "ARL Annual Salary Survey 2013-2014" (June 23, 2014), https://publications. arl.org/ARL-Annual-Salary-Survey-2013-2014/; Martha Kyrillidou and Shaneka Morris, "ARL Annual Salary Survey 2014-2015" (June 10, 2015), https://publications.arl.org/ARL-Annual-Salary-Survey-2014-2015/; Martha Kyrillidou and Michael O'Connor, "ARL Annual Salary Survey 1999-2000" (ARL, 2000); Martha Kyrillidou and Karen Wetzel, "ARL Annual Salary Survey 2000-2001" (ARL, 2001); Martha Kyrillidou and Mark Young, "ARL Annual Salary Survey 2001-2002" (ARL, 2002); Martha Kyrillidou and Mark Young, "ARL Annual Salary Survey 2002-2003" (ARL, 2003); Martha Kyrillidou and Mark Young, "ARL Annual Salary Survey 2003-2004" (ARL, 2004); Martha Kyrillidou and Mark Young, "ARL Annual Salary Survey 2004-2005" (ARL, 2005); Martha Kyrillidou and Mark Young, "ARL Annual Salary Survey 2005-2006" (August 29, 2006), https://publications.arl. 
org/ARL-Annual-Salary-Survey-2005-2006/; Martha Kyrillidou and Mark Young, "ARL Annual Salary Survey 2006-2007" (October 23, 2007), https://publications.arl.org/ARL-Annual-Salary-Survey-2006-2007/; Shaneka Morris, "ARL Annual Salary Survey 2015-2016" (April 28, 2017), https://publications.arl.org/ARL-Annual-SalarySurvey-2015-2016/; Shaneka Morris, "ARL Annual Salary Survey 2016-2017" (July 12, 2018), https://publications. arl.org/ARL-Annual-Salary-Survey-2016-2017/.

33. Association of Research Libraries website, "Who We Are," https://www.arl.org/who-we-are/ [accessed July 25, 2019].

34. Association of Research Libraries website, “List of ARL Members," https://www.arl.org/list-of-arl-members/ [accessed August 8, 2019].

35. Bureau of Labor Statistics, U.S. Department of Labor, “Women's Median Earnings 82 Percent of Men's in 2016," Economics Daily (March 8, 2017), https://www.bls.gov/opub/ted/2017/womens-median-earnings-82-percentof-mens-in-2016.htm.

36. Social Security Administration website, “Cost-Of-Living Adjustments," https://www.ssa.gov/OACT/cola/ colaseries.html [accessed July 22, 2019].

37. Kathy Rosa and Kelsey Henke, "ALA Office for Research and Statistics 2017 ALA Demographic Study" (2017), www.ala.org/tools/sites/ala.org.tools/files/content/Draft\%20of\%20Member\%20Demographics\%20Survey\%2001-11-2017.pdf.

38. AFL-CIO Department for Professional Employees, “Library Professionals: Facts \& Figures," https://dpeaflcio.org/wp-content/uploads/Library-Workers-Facts-Figures-2019.pdf [accessed August 9, 2019]. 